\title{
RTDF2007-46015
}

\section{DEVELOPING STRATEGIES FOR MAINTAINING TANK CAR INTEGRITY DURING TRAIN ACCIDENTS}

\author{
David Tyrell \\ Karina Jacobsen \\ Brandon Talamini \\ Michael Carolan \\ Volpe National Transportation Systems Center \\ Cambridge, Massachusetts, USA
}

\section{ABSTRACT}

Accidents that lead to rupture of tank cars carrying hazardous materials can cause serious public safety hazards and substantial economic losses. The desirability of improved tank car designs that are better equipped to keep the commodity contained during impacts is clear. This paper describes a framework for developing strategies to maintain the structural integrity of tank cars during accidents.

The target of this effort is to design a tank car capable of surviving impacts without loss of lading at twice the impact speed of current equipment (or, equivalently, is capable of absorbing four times the impact energy). The methodology developed breaks down the process into three steps:

1. Define the impact scenarios of concern

2. Choose strategies to mitigate failure modes present in each scenario

3. Design and select technology and tactics to implement the mitigation strategies

The railroad accidents involving tank cars that occurred in Minot, ND, in 2002, and Graniteville, SC, in 2005, are examined to define the impact scenarios. Analysis of these accidents shows that two car-to-car impact scenarios are of greatest concern: head impact, where railroad equipment impacts the end of a tank car and possibly overrides it, and shell impact, where the tank car is impacted on its side, possibly off center.

A conceptual design that can protect its lading at twice the impact speed of current equipment in the car-to-car impact scenarios is being developed. The conceptual design includes four functions to meet the impact requirements: blunts the impact loads, absorbs collision energy, strengthens the tank, and controls the load path to assure that loads are blunted and that energy is absorbed before the tank is loaded.
Preliminary studies of available weight and space, strategies for increasing energy absorption, and strategies for strengthening the head and shell are ongoing; this paper describes the current results of these studies. Additional studies are also ongoing. The steps required to complete this effort are also described.

\section{INTRODUCTION}

In support of the Federal Railroad Administration (FRA), the Volpe National Transportation Systems Center (Volpe Center) is conducting research on improving tank car safety. The results of this research are being used to help form the technical basis for ongoing tank car safety rulemaking, which is being carried out by the Pipeline and Hazardous Material Safety Administration (PHMSA) and FRA. This rulemaking activity is focused on tank cars which carry materials that are a Toxic Inhalation Hazard (TIH), such as chlorine. This research is intended to support the activities described in a press release issued by FRA on January 16, 2007 [1]:

"Our goal is to jump beyond incremental design changes," [FRA Administrator Joseph H.] Boardman said. "We and our partners are looking to apply the latest research and advanced technology to provide increased safety for rail shipments posing the greatest safety risk," he explained, noting that FRA is considering issuing new, more robust Federal design standards for hazardous materials tank cars and hopes to issue a final rule in 2008.

The goal set for this research is to double the car-to-car impact speed for which integrity of the tank can be maintained and the commodity contained. This paper describes one aspect of the tank car safety research-the development of an improved conceptual design. The purpose of the conceptual design is to show that the chosen goal can be met. Results from the development of the improved conceptual design are

This material is declared a work of the U.S. Government and is not subject to copyright protection in the United States. Approved for public release; distribution is unlimited. 
being used to estimate benefits and costs, demonstrate techniques for evaluating compliance with selected requirements, and exemplify technologies needed to increase tank integrity in accidents. Companion papers describe other aspects of this research, including full-scale testing of the baseline equipment [2], material failure modeling [3], train collision dynamics modeling [4], and an overview of the entire research effort in support of the PHMSA and FRA rulemaking activity [5]. While significant progress toward the goal has been made, the research is not yet completed.

\section{APPROACH}

The approach used in conducting this research is illustrated in the flow diagram shown in Figure 1.

1. Define the collision scenarios of concern. The accidents identify the conditions for which the commodity is to be contained. These conditions include the collision or derailment speed, the train and other objects, and the track conditions $[4,6]$. The goal in developing the collision scenarios of concern is to develop a limited number of scenarios that bound the range of conditions leading to loss of lading. These scenarios are used as the basis for evaluating the effectiveness of alternative tank car designs.

2a. Develop information on the features of existing designs that influence crashworthiness. Information on the design details of the equipment-the geometry of the structure, material properties, welding and attachment details-are developed for use in analytic models and in the development of test articles [7, 8].

2b. Develop potentially improved designs. A clean-sheet design is being developed. The functions and features of the clean-sheet design are also being evaluated to determine if they can be incorporated into existing designs. This paper focuses on this aspect of the research.

3. Evaluate the effectiveness of existing design and potentially improved design equipment. From postaccident results, it can be seen how effective the equipment was in containing the commodity. Gaps and uncertainties exist in the information available from accidents. Analyses and tests are used to fill in these gaps [2, 3, 5, 6, 7, and 8]. Analytic models and tests, similar to those developed and conducted for the conventional equipment, are used to evaluate the effectiveness of the alternative designs.

4. Compare the effectiveness of the alternative designs with the existing designs. For a given accident scenario of concern, comparisons are made in terms of the maximum collision speed for which the commodity would be contained.

5. In order to evaluate the crashworthiness of existing and alternative designs, analytic tools and testing techniques are developed and refined. Accidents provide information for comparison to analytic model predictions and help provide some level of assurance of the fitness of the models. Much is often unknown about an accident, such as the precise collision speed and exact initial conditions for the equipment. Testing provides more detailed information for comparison with analysis predictions [2].

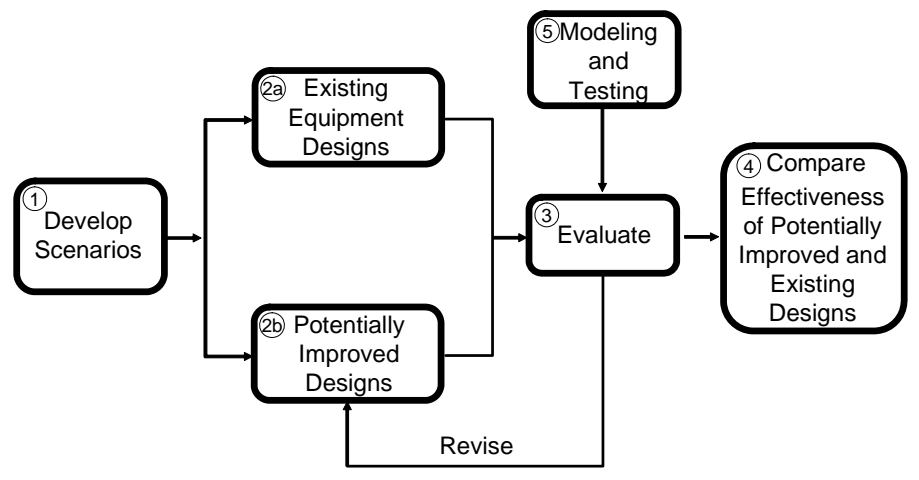

\section{Figure 1. Flow Diagram, Tank Car Safety Research Principal Tasks}

This approach has been successfully applied to several research projects in the area of rail equipment crashworthiness. Examples include development of crush zones (referred to as crash energy management or CEM) for passenger equipment $[9,10,11]$, a state-of-the-art cab car end frame [12] for preserving the operator's space, an improved workstation table for limiting abdominal injury [13], and an optimized commuter seat design [14] for protecting both rear and forward facing passengers. Concepts developed with this approach include deformable locomotive short hood and collision posts [15] for preserving the operator's space and inflatable structures for locomotive operator protection [16].

\section{IMPROVED DESIGN DEVELOPMENT}

Collision dynamics and structural response, as well as material failure are the tools used in the design development. The collision dynamics determine how the loads are applied to the structure. The structural response, in combination with the collision dynamics, determines the magnitude of the loads. For a given impact speed, if the structure is relatively soft, then the impact loads will remain low; if the structure is relatively stiff, then the loads may become large. The magnitude of the load in combination with the structural response and material properties determines if material failure occurs. For a given material and load, material failure may occur with an impacting object that focuses the load on the tank, while material failure may not occur for an impacting object that disperses the load on the tank [3].

Figure 2 shows a flowchart of the process for developing the improved tank car design. The design requirements describe the desired performance of the tank car in detail. Using these, concepts for meeting the requirements were generated, rated, ranked, and selected. Preliminary design

This material is declared a work of the U.S. Government and is not subject to copyright protection in the United States. Approved for public release; distribution is unlimited. 
studies to support the refinement of the selected concept are ongoing. This paper describes the selected design concept, as well as results from preliminary design studies.

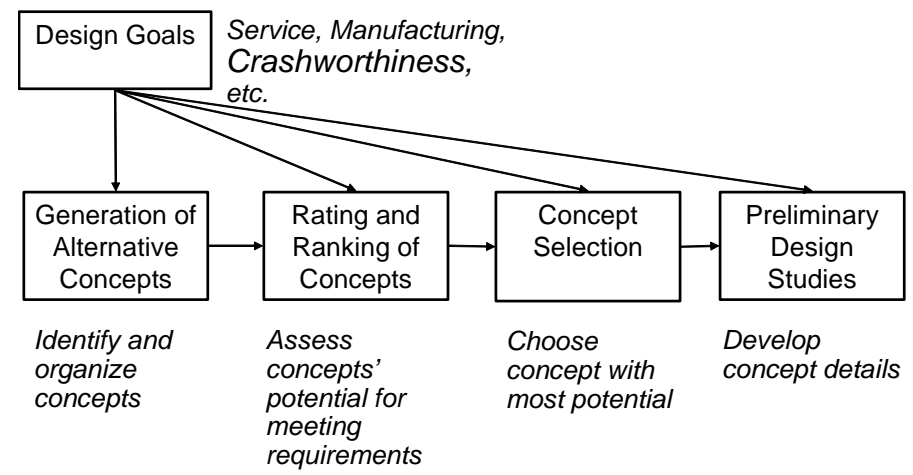

Figure 2. Design Development Process

\section{Key Design Requirements}

The design requirements for all of the conventional aspects-service, manufacturing, inspection, test, and maintenance-do not vary substantially from the current requirements for conventional tank cars. The greatest difference is in the crashworthiness requirements. Requirements have been added that prescribe how the tank car must perform in selected impact conditions.

Figure 3 is a schematic of the head impact design requirement. The tank car must be able to retain its lading for an impact with a rigid fixed punch with a blunt end. The impact occurs below the tank's centerline. The goal is to increase the amount of impact energy for which the tank can contain the commodity by a factor of four. Meeting this goal would double the impact speed for which the integrity of the tank can be maintained.
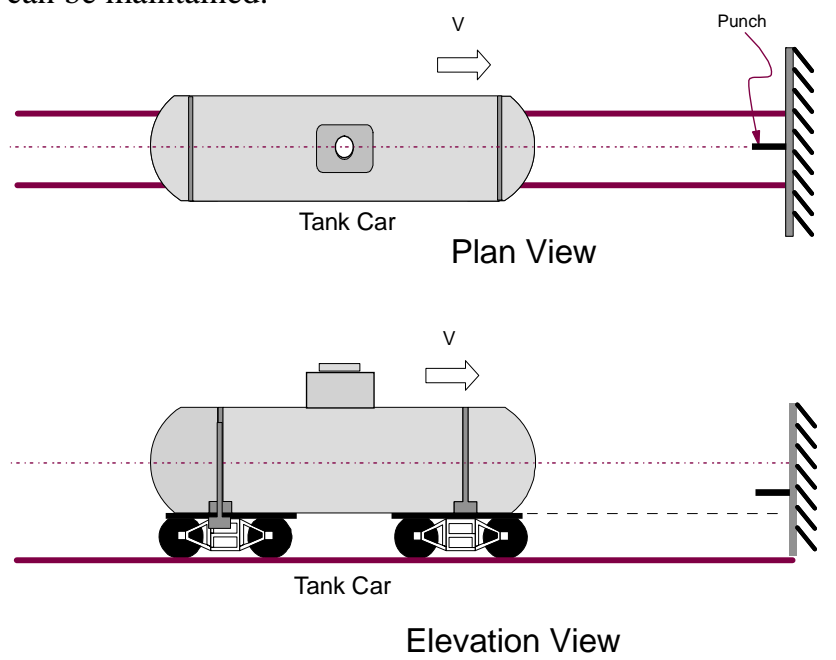

Figure 3. Schematic of Head Impact Requirement

Figure 4 is a schematic of the shell impact design requirement. In this scenario, the side of the tank car is impacted by a ram car with a blunt punch. The impact occurs at the tank's centerline. The improved tank car must be able to retain its lading for an impact with four times the energy as the impact for which the baseline tank car can retain its lading. As for the head impact design requirement, meeting this goal would double the impact speed for which the integrity of the tank can be maintained. As described in the references [2 and 3], the speed for which tank integrity is maintained depends on the height and width of the nose of the blunt punch. The relative increase in performance sought is the same for a wide range of nose sizes.

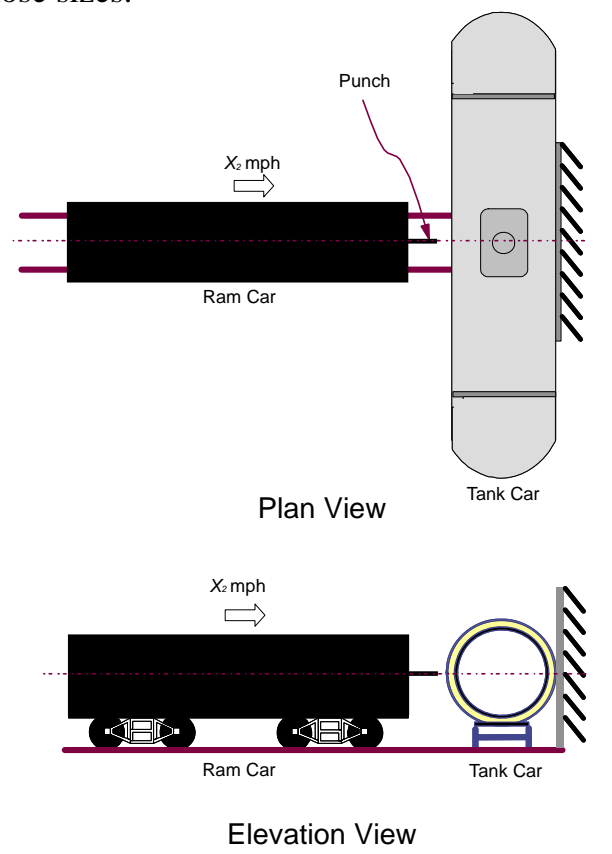

Figure 4. Schematic of Shell Impact Requirement

Figure 5 for the shell impact illustrates the connection between speed and the energy the tank car must be able to absorb without loosing its lading. The initial kinetic energy of the moving equipment is translated into the work done to elastically and plastically deform the structure. These impact requirements drive the design differences between the improved design and conventional design tank cars.

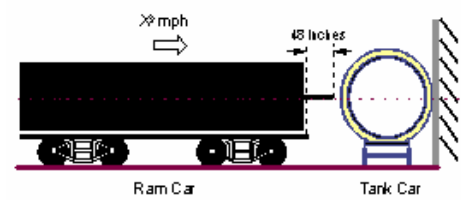

Collision Energy: $\mathrm{KE}=1 / 2 \mathrm{mV}_{\mathrm{i}}^{2}$

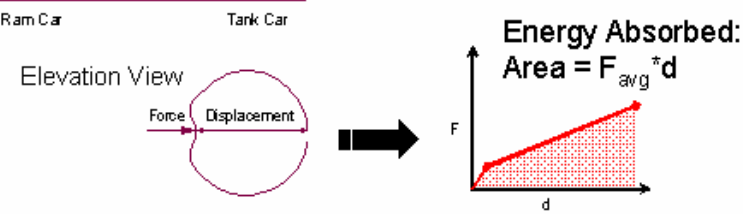

Energy to Maintain Tank Integrity: $1 / 2 \mathbf{m V}_{\mathrm{i}}^{2}=\mathbf{F}_{\mathrm{avg}}{ }^{*} \mathbf{d}$

Figure 5. Initial Kinetic Energy and Energy Absorbed by Tank Car in Shell Impact

This material is declared a work of the U.S. Government and is not subject to copyright protection in the United States. Approved for public release; distribution is unlimited. 


\section{Selected Concept}

Aspects of the conceptual design include how the design is intended to function and what features are included to perform these functions. The functions are qualitative descriptions of how the car structure is intended to behave in the selected impact scenarios. The design features are intended to perform the desired functions. The form is the realization of a design with these features and functions, which would be a constructible design. Several iterations of a constructible design, with component tests and associated analyses, may be necessary before a final production design is developed.

Table 1 lists the functions and associated features of the selected concept. The conceptual design must perform the following four functions to meet the impact requirements associated with head and shell impact scenarios: blunt the impact loads, absorb collision energy, strengthen the tank, and control the load path to assure that loads are blunted and that energy is absorbed before the tank is loaded.

Table 1. Conceptual Design Functions and Features

\begin{tabular}{|l|l|}
\hline \multicolumn{1}{|c|}{ Functions } & \multicolumn{1}{c|}{ Features } \\
\hline $\begin{array}{l}\text { Blunted impact } \\
\text { loads }\end{array}$ & $\begin{array}{l}\text { Sacrificial structure that } \\
\text { shields tank and absorbs } \\
\text { energy }\end{array}$ \\
\hline $\begin{array}{l}\text { Collision energy } \\
\text { absorbed }\end{array}$ & $\begin{array}{l}\text { Reinforcement of head and } \\
\text { shell }\end{array}$ \\
\hline Strengthened tank \\
\hline $\begin{array}{l}\text { Controlled load } \\
\text { path to tank }\end{array}$ & $\begin{array}{l}\text { Carbody supports service } \\
\text { loads }\end{array}$ \\
\hline
\end{tabular}

\section{Blunt Impact Load}

Head shields on current cars principally act to blunt the impact load. The shield makes the size of the impacting object appear larger to the tank, spreading the load over a greater area, and makes any sharp edges appear to have a larger radius, dispersing the stress in the tank. By doing so, the energy required to rupture the tank is increased. The concept is to include a feature which can blunt the impact load on any part of the tank, that is, to cover the entire tank with a shield. Figure 6 illustrates the functioning of such a shield.

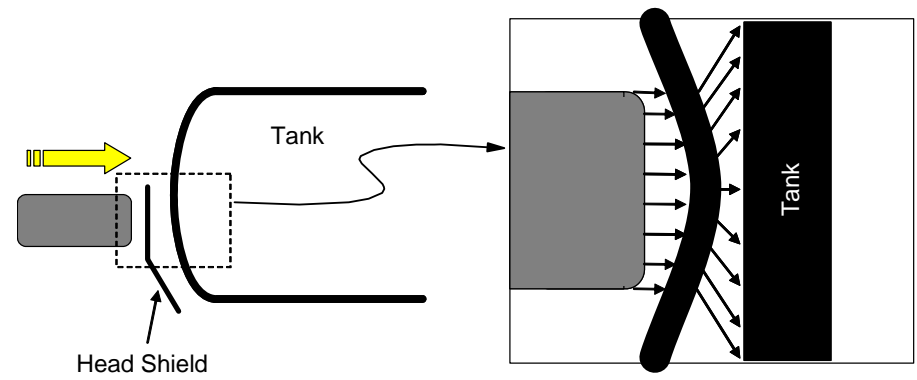

\section{Absorb Collision Energy}

The addition of an energy absorption component between the shield and the tank can further increase the energy required to rupture the tank. In essence, the energy absorption layer decreases the speed of the impact experienced by the tank. The energy absorption layer can significantly slow down the impacting object before the tank is significantly loaded. Figure 7 illustrates the combined functioning of a shield and energy absorption component.

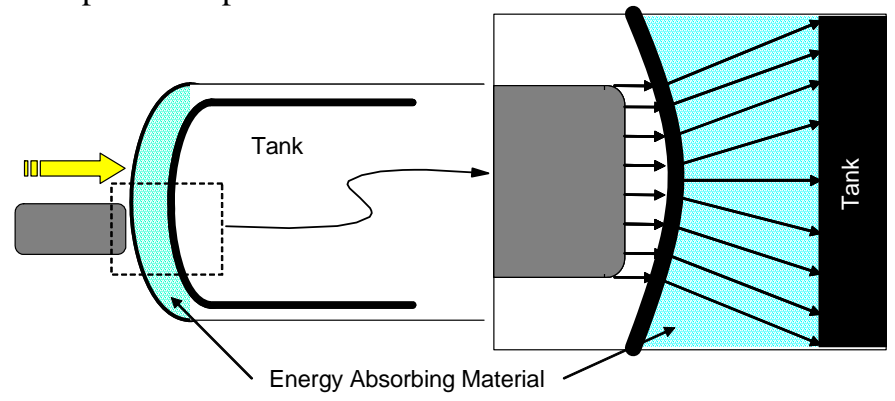

Figure 7. Schematic Illustration of Combined Head Shield and Energy Absorption Component Function

\section{Strengthen Tank}

Strengthening the tank allows an energy absorption component to crush at a higher load. As suggested by Figure 5, the higher the load required to deform the tank car (and its components), the more energy required to rupture the tank car. Since the head can 'snap through' at a relatively low load [7], the energy absorption crush load that can be supported without reinforcement is relatively low. Similarly, the shell tends to ovalize and dish at a relatively low load when impacted [2], limiting the amount of energy that can be absorbed without reinforcement.

If the tank remains the main service load bearing structure, then the potential for weldments to lead to fatigue failures is of concern. In such a case, bonding the reinforcement to head and shell is a potential option. If the service load bearing structure is separate from the commodity tank, and the tank does not experience cyclic service loads, then the potential for fatigue failure is much lower. In such a case, directly welding to the head and shell may be a viable option.

\section{Load Path}

Accident history suggests that rupture can initiate anywhere on the tank. Ruptures are more likely at certain locations on the tank-below the belt line and at the ends of the car. However, cars appear to have been ruptured owing to impacts near the draft sill/body bolster and on the top. These accident results suggest that the entire car should be shielded and that collision energy should be absorbed before the tank is impacted. In order to accomplish this function, a separate carbody structure supports the service loads.

Figure 6. Schematic Illustration of a Head Shield Spreading Load and Dispersing Stress

This material is declared a work of the U.S. Government and is not subject to copyright protection in the United States. Approved for public release; distribution is unlimited. 


\section{Integrated Design}

Figure 8 shows a schematic of the features integrated into a conceptual design. Potentially, these features could be applied incrementally to existing designs, working from the inside out. The tank could be strengthened with bonded stiffeners alone. As described in the preliminary design study section of this paper, such stiffeners have the potential to double the energy required to rupture the tank. A sacrificial structure for blunting the load and absorbing energy could be further added. The tank stiffeners and sacrificial structure together could increase the energy required to rupture the tank by a factor of four. Such a car would be at least somewhat more vulnerable near the draft sill/body bolster attachments, even if these attachments act as structural fuses and fail in a prescribed manner for prescribed loads. Impact loads that bypass the sacrificial structure could be introduced to the tank through the Achilles' heel of the draft sill/body bolster. The external carbody would eliminate this vulnerability and result in the integrated conceptual design. For example, the continuous center sill design relieves the tank from bearing the in-train buff and draft forces and continues to be used in DOT 105A500W tank cars built for carbon dioxide service.

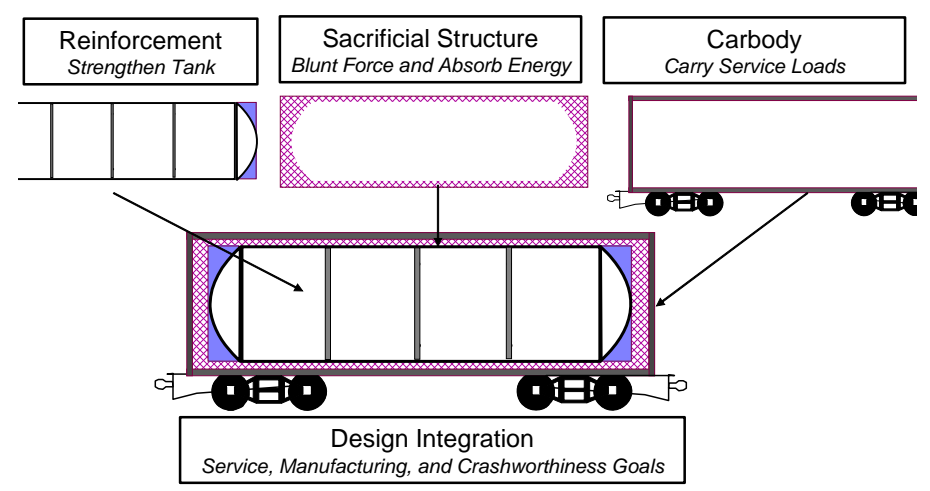

Figure 8. Schematic Illustration of the Integrated Conceptual Design

\section{PRELIMINARY DESIGN STUDIES}

Preliminary studies of available weight and space, strategies for increasing energy absorption, and strategies for strengthening the head and shell are ongoing. Managed energy absorption is necessary to achieve improvements in tank car crashworthiness. Weight and space are primary constraints on energy absorption features. The collapse strength of the support structure is also a constraint on energy absorption features. The stronger the tank, the greater the load that the energy absorbing structure may crush at, and the smaller the crush distance required for a specified amount of energy absorption.

This section describes the current results of the preliminary design studies. Only the results for the head impact scenario are described. Parallel results have been achieved for the shell impact scenario. Studies on additional design details of the sacrificial structures, including means of blunting the load and of the carbody structure, are also ongoing. The results of the This material is declared a work of the U.S. Government and is not subject to copyright protection in the United States. Approved for public release; distribution is unlimited. preliminary design studies will be described in follow-on papers once the studies have been completed.

\section{Weight and Space}

In order to achieve adequate performance of a new car design, it may be necessary to change the shape and size of the tank car. Such changes could result in issues related to how the commodity is loaded and unloaded. Some facilities will have to re-evaluate the top platform design in order to access the top fittings. If multiple cars are loaded/unloaded at one time, then car spacings where such fixtures are located will need to be evaluated, perhaps requiring some to be redesigned. Additionally, it is understood that the design must account for placement of safety appliances. The details of the final car layout will be defined in the next phase of design development and discussed in future work.

The baseline car chosen for this study is a DOT 105J500W car, the same class of tank car used in the full-scale crash tests [2]. This baseline car is constructed to Association of American Railroads (AAR) plate B clearance standards [17].

The clearance standard dictates the maximum car height, width, and truck center spacing for compliant cars. For plate B, the maximum allowable height of any portion of the car is 15'1 " above top-of-rail. At the maximum allowable width of 10'8”, truck centers cannot exceed 41'-3”. Figure 9 shows the envelope for equipment built to plate B.

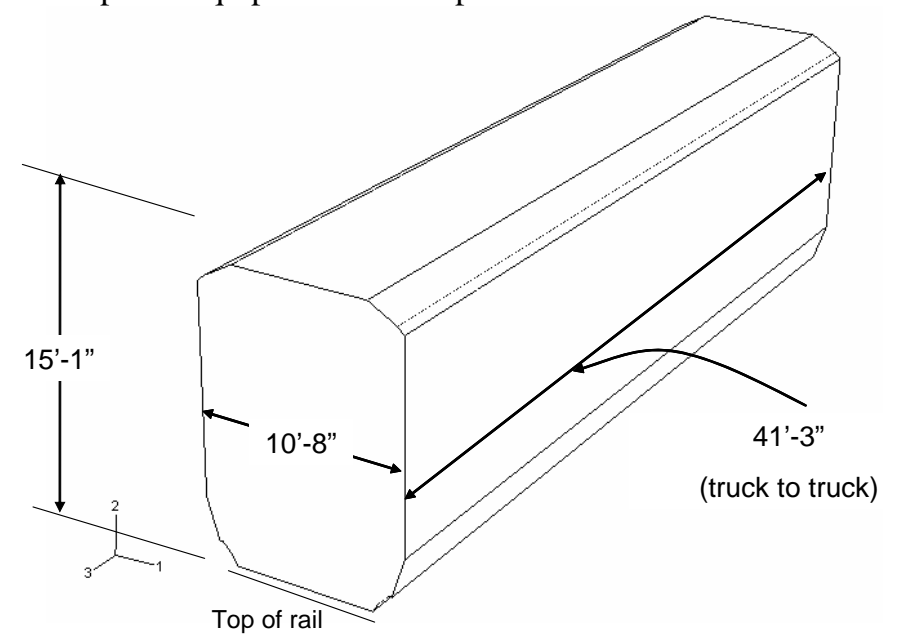

Figure 9. Maximum Dimensions for Plate B

For a car with the maximum distance between truck centers, the length of structure outboard of the trucks must also be considered in the car's design. The swingout at the ends of the car cannot exceed the swingout at the center of the car on a $13^{\circ}$ curve [17]. A car built to plate B with maximum distance between truck centers has a swingout at the center of the car of $53 / 4$ ". By extending the length of the car outboard of the trucks until this same swingout is achieved at the end of the car, a maximum overall car length of 57'-10" can be achieved.

The baseline car's tank has an outer diameter of 8'-6 3/10" and a nominal capacity of 17,300 gallons. This tank has a 1'- 
7/8” clearance on either side before encountering the maximum allowable car width. This clearance effectively limits the maximum amount of energy absorbing material that can be placed around the tank. As illustrated in Figure 5, increasing the thickness of material being crushed at a given force will result in more energy being absorbed.

Since the clearance diagram width cannot be extended, the only way to include more space for energy absorbing material around the tank's circumference is to decrease the tank's diameter. Figure 10 shows a tank with a diameter 5" less than the baseline overlaid on the baseline tank. The tank length has been extended to maintain the same volume as the baseline tank. With a head-to-head length of approximately 48', sufficient clearance exists for placement of new structure surrounding the head.

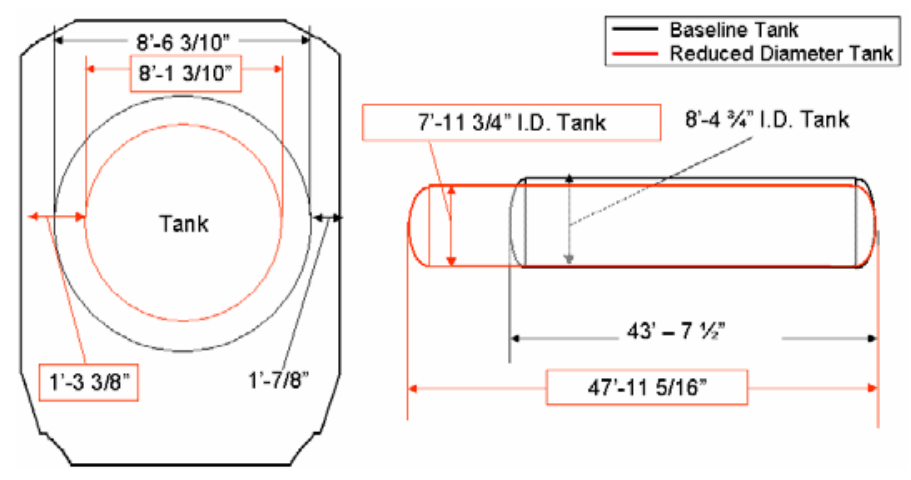

Figure 10. Baseline Tank and Reduced Diameter Tank

One concern associated with the addition of new structure to the car is the additional weight that this will contribute. For the improved crashworthiness tank car, the maximum allowable weight is 286,000 lb. The new design includes many of the same features of a conventional tank car, including the tank assembly, truck assemblies, safety appliances, and an equal lading capacity of 90 tons of chlorine. In addition, the new design will include a strengthened tank, energy absorbing material, and a structural frame to bear the service loads.

Table 2 shows the weights of components common to both conventional and improved crashworthiness tank cars. These preliminary values are given to estimate the amount of weight that is available for new structure. Based on the weights of existing tank car components and the 286,000 lb limit, approximately 39,000 lb are available for new structure. This available weight comes from increasing the car weight and from incorporating the functions of the baseline car's jacket and the stub sill/body assemblies into alternative components.
Table 2. Weight Breakdown of Tank Car Components

\begin{tabular}{|l|r|}
\hline & Weight (lbf) \\
\hline Bare Tank ( $\mathrm{t}=0.777 ")$ & 38280 \\
\hline Truck Assemblies (2) & 20580 \\
\hline Coupler/Draft Gear Assemblies (2) & 2300 \\
\hline Air Brake Assembly & 1310 \\
\hline Fittings and Housing Assembly & 1300 \\
\hline Manway & 1300 \\
\hline Ladders/Handholds/Railings & 1100 \\
\hline Handbrake Assembly & 420 \\
\hline Paint/Markings & 100 \\
\hline & \\
\hline Chlorine & 180000 \\
\hline & \\
\hline Subtotal & 246690 \\
\hline Available for new structure & 39310 \\
\hline
\end{tabular}

\section{Target Energy Absorption and Kinematics}

The crashworthiness performance of a tank car is defined by its ability to maintain tank integrity for a given impact condition at a minimum speed. Figure 5 illustrates the relationship between the collision speed in the shell collision scenario and the energy absorption requirement for a tank shell to maintain tank integrity. For the baseline tank shown in Figure 11, the shaded area under the force-indentation curve up to the point of possible rupture represents the energy absorption required for the head to maintain tank integrity. The tank car research goal is to increase the collision speed for which tank car integrity can be maintained by a factor of two. An improved tank car that can withstand twice the speed will have energy absorption requirements four times that of the baseline tank car.

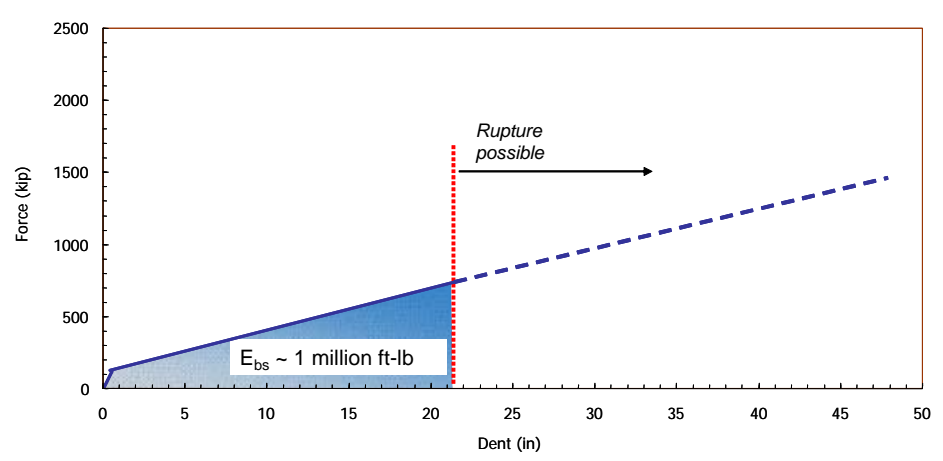

Figure 11. Idealized Force-Indentation Characteristic for a Conventional Head

Figure 12 illustrates the desired kinematic sequence of the conceptual design tank car for the head impact requirement. The conceptual design includes the crashworthiness features described in Table 1 and illustrated in Figure 8. By designing a tank car to crush in the prescribed sequence shown, the collision unfolds in a more predictable and controlled manner. For the head scenario, in state 1 , initial contact is made between the indenter and the outer tank carbody. In state 2, a sacrificial energy absorbing layer begins to collapse. The footprint of the

This material is declared a work of the U.S. Government and is not subject to copyright protection in the United States. Approved for public release; distribution is unlimited. 
indenter is spread over a wider area; by state 3 , a less severe and more distributed load is applied to the commodity tank. In state 4 , the head deforms until rupture occurs in state 5.

\section{State \\ 1 Initial Punch Contact with Carbody}

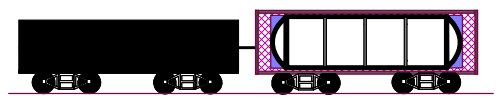

2 Energy Absorbed by Crushable Structure

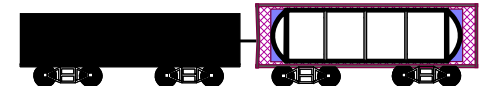

3 Crushable Structure Collapses, Contact with Head

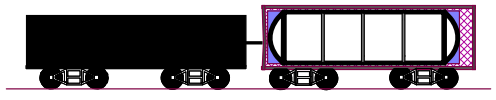

4 Head Crushes

5 Head Ruptures

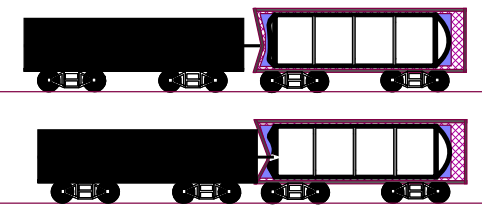

Figure 12. Head Impact Scenario: Improved Tank Car Target Kinematic Sequence of Events

Figure 13 shows the energy absorption requirements of an improved design. The desired force-indentation characteristic was developed using the space constraints addressed earlier in this paper and the features identified in Table 1 . The resultant curve represents an improved tank that has a sacrificial structure that absorbs energy and distributes the load applied to a strengthened head.

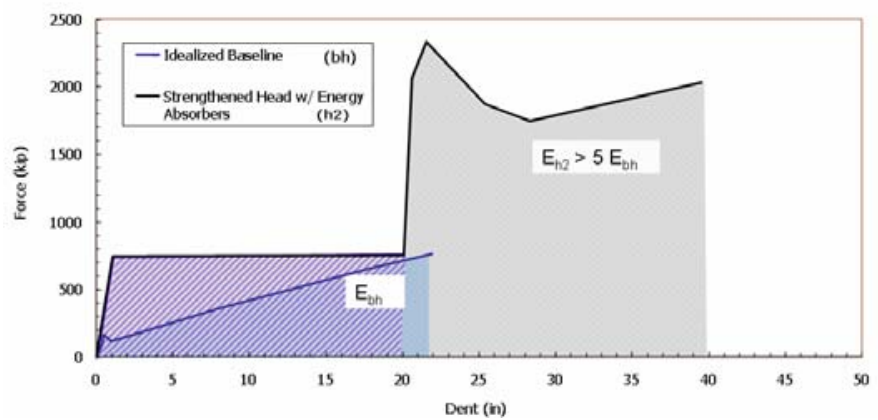

Figure 13. Head Force-Indentation Characteristics

A desired kinematic sequence for the conceptual design tank car in a shell impact and a target force-indentation characteristic for the shell have also been developed. Figure 14 illustrates the shell kinematic sequence, and Figure 15 shows the target force/indentation characteristic. The desired kinematic sequence for the shell impact parallels that for the head impact. In state 1 , initial contact is made between the indenter and the outer tank carbody. In state 2, a sacrificial energy absorbing layer begins to collapse. The footprint of the indenter is spread over a wider area, and by state 3 , a less severe and more distributed load is applied to the commodity tank. In state 4 , the head deforms until rupture occurs in state 5.

This material is declared a work of the U.S. Government and is not subject to copyright protection in the United States. Approved for public release; distribution is unlimited.

\section{State}

1 Initial Punch Contact with Carbody

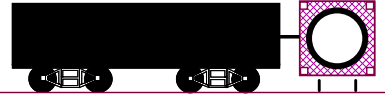

2 Energy Absorbed by Crushable Structure

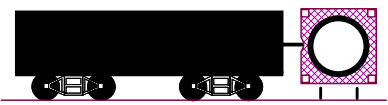

3 Crushable Structure Collapses, Contact with Shell

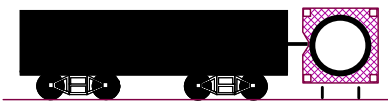

4 Shell Crushes

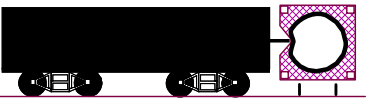

5 Shell Ruptures

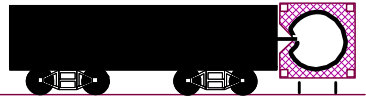

Figure 14. Shell Impact Scenario: Improved Tank Car Target Kinematic Sequence of Events

Figure 15 shows force-indentation characteristics for the baseline tank, a tank with an energy absorbing structure added, and a reinforced tank with an energy absorbing structure. Adding just an energy absorbing structure to a baseline shell can potentially increase the energy for which tank integrity is maintained by a factor of 2 , increasing the speed for which tank integrity is maintained by 50 percent. Further, strengthening the shell and adding an energy absorbing layer potentially increases the energy for which tank integrity is maintained by four and doubles the speed for which tank integrity is maintained.

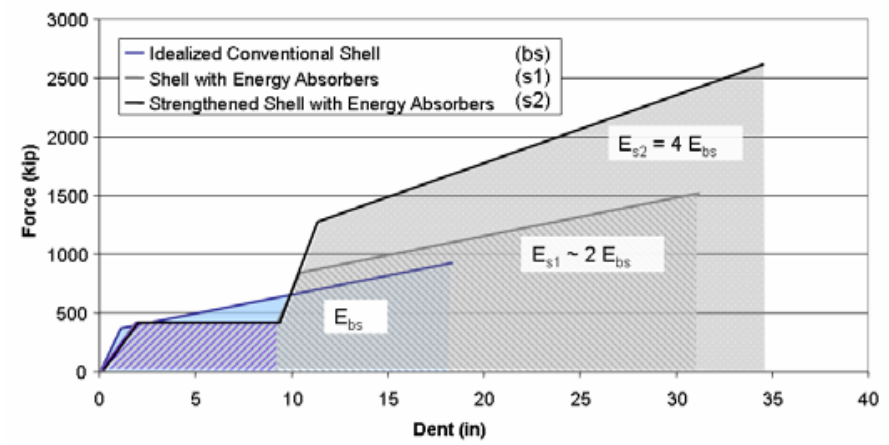

Figure 15. Shell Force-Indentation Characteristics

Design studies to determine how to achieve the desired kinematics and the target force-indentation characteristics for the head and shell are ongoing. If structures that meet these design goals can be developed, then an improved tank car can meet the impact conditions illustrated in Figures 3 and 4.

\section{Head Strengthening}

As illustrated in the previous section, the capacity of the energy-absorbing components may be extended by increasing 
the strength of the commodity tank in its role as a support structure. Various means of increasing the strength of the tank are compared in this section.

Shell structures (such as aircraft fuselages and ship hulls) are often reinforced with ribs; that is, with beams connected along their length to the shell. This arrangement increases the bending resistance of the shell with little additional weight. Ribs may be attached by welding, glue bonding, riveting, or they may be formed directly into the shell. Figure 16 illustrates a schematic of spider web arrangement of ribs on a tank car head. This arrangement is investigated with finite element analysis with ribs that have a cross-sectional moment of inertia of $12.6 \mathrm{in}^{4}$ and a cross-sectional area of $12.6 \mathrm{in}^{2}$. The head has a thickness of 0.777 in.

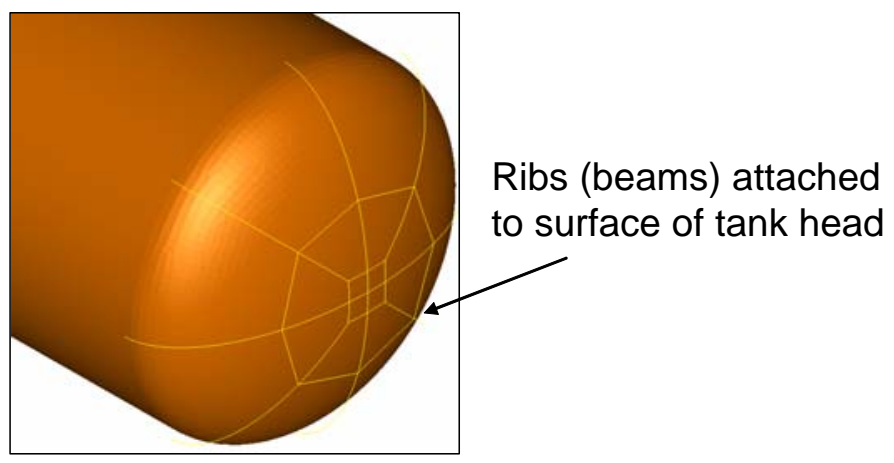

Figure 16. Tank Head Reinforce with Spiderweb
Arrangement of Ribs

Figure 17 shows the deformed shape of the baseline head, as well as the deformed shape of the head reinforced with ribs for an impact in the center of the head with a blunt punch. The figure shows the maximum indentation of both heads when they have absorbed 1 million ft-lb of energy. The reinforced head has deflected significantly less than the baseline head for the same amount of absorbed energy.

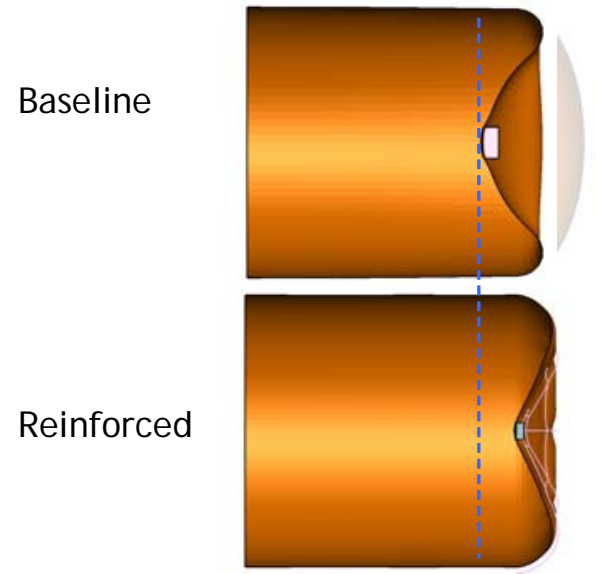

Figure 17. Indentations of Baseline and Reinforced Head, Center Impact with a Blunt Punch

Figure 18 shows the force-indentation characteristics for the baseline and reinforced heads for an impact in the center of the head. The energy required to deform the head is the integral of the force-indentation curve. The area under the force-indentation characteristic for the reinforced head is more than twice the area under the characteristic for the baseline head. Figure 18 also shows the force-indentation characteristic for a head reinforced by thickening the material to $1.11 \mathrm{in}$. The area under that curve is greater than the area under the baseline curve; however, it is significantly less than the area under the curve associated with the head reinforced with ribs.

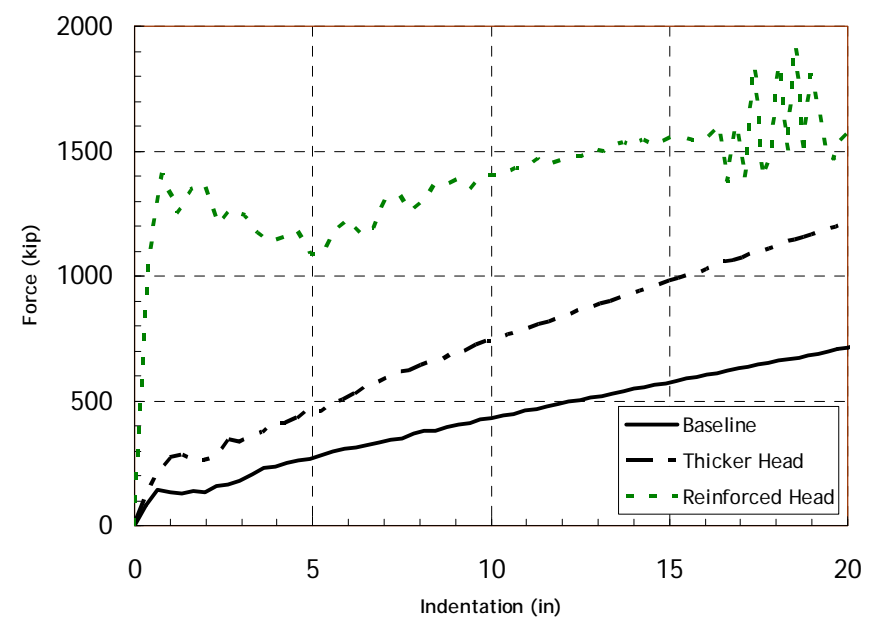

Figure 18. Force/Indentation Characteristics, Baseline Head, Head Reinforced with Ribs, and Thickened Head, Center Impact with a Blunt Punch

Figure 19 shows the undeformed shaped of the reinforced head, as well as the deformed shape after an impact from a blunt punch at a location away from the center of the head. This location was chosen to be between the reinforcements, where they would likely be least effective. Nevertheless, the deformed shape suggests that the reinforcements are indeed still effective.

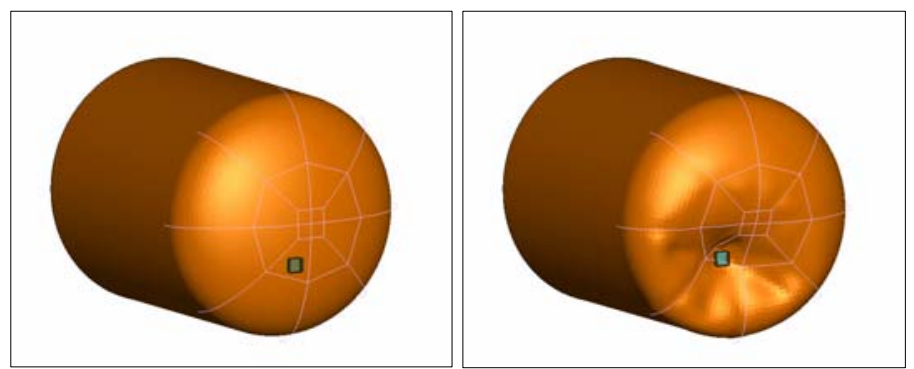

Figure 19. Indentation of Reinforced Head, Offset Impact with a Blunt Punch

Figure 20 shows the force-indentation characteristics for the baseline and reinforced heads for an offset impact with a blunt punch. The force levels are not as high as for the center impact, for both the baseline and reinforced head. However, the area under the force-indentation characteristic for the reinforced head is again more than twice the area under the characteristic for the baseline head.

This material is declared a work of the U.S. Government and is not subject to copyright protection in the United States. Approved for public release; distribution is unlimited. 


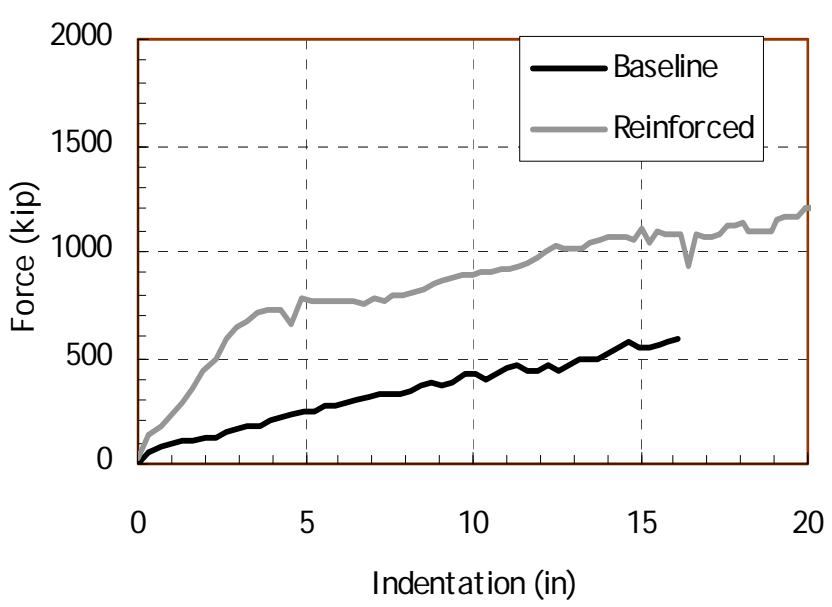

Figure 20. Force/Indentation Characteristics, Baseline Head and Head Reinforced with Ribs, Offset Impact with a Blunt Punch

The head reinforced with ribs can also support an energy absorption component that crushes at a higher load than the baseline and thickened heads. Alternative means of absorbing energy are currently being investigated, including plastic foams, aluminum honeycomb, and steel sandwich structures. This research suggests that a tank car reinforced with ribs and such an energy absorbing structure could maintain tank integrity for an impact with four times the energy as the baseline tank car.

\section{SUMMARY AND NEXT STEPS}

Research is being conducted to support the rulemaking activities of FRA related to the TIH tank cars. Research results to date suggest that an improved design tank car can double the car-to-car impact speed for which integrity of the tank is maintained over that of conventional tank car designs. Reinforcing the head alone can potentially increase the maximum impact energy by a factor of 2, increasing the maximum containment speed by 50 percent. Results suggest that reinforcing the head and adding an energy absorbing layer increases the tank integrity energy by four times and doubles the maximum containment speed. While not presented in the paper, similar results have been obtained for the impact resistance of the shell.

The results of this research are being shared with the Dow/Union Pacific/Union Tank Car Next Generation Railroad Tank Car. Cooperative activities include the full-scale shell impact testing of conventional equipment. As described in a companion paper [5], FRA supported the Volpe Center in designing these tests and simulating the results of the tests with simplified models. Dow Chemical supported Applied Research Associates Inc. in conducting simulations of the test using a detailed model and supported the Transportation Technology Center Inc (TTCI) in implementation of the tests.

While information is being shared, the design development activities supported by Dow Chemical are separate and distinct from the design development activities being conducted by the Volpe Center in support of FRA. In the process chosen by FRA, an overall strategy is evolved into a single concept with required functions and features. These features are then refined into detailed forms with preliminary design studies. This approach has been used to develop crush zones for passenger equipment [9, 10, and 11], the state-of-the-art cab car end frame design [12], and improved locomotive crashworthiness features [15]. Alternative design development approaches exist; any of which may result in an improved tank car conceptual design that differs from the conceptual design described in this paper. The performance achievable with such an alternative may exceed the performance associated with the conceptual design described in this paper.

Preliminary design studies are ongoing for the further refinement of the conceptual tank car design presented in this paper, including ongoing studies of available weight and space, strategies for increasing energy absorption, and strategies for strengthening the head and shell. Studies on additional design details of the sacrificial structures, including means of blunting the load, and the carbody structure, are also ongoing.

In order to achieve the required performance, it is necessary to change the size of the tank car. Such changes will affect the how the commodity is loaded and unloaded. In addition, it is understood that the design must account for placement of safety appliances. The details of the final car layout will be defined and discussed in future studies.

Component tests of a head strengthening strategy, as discussed in this paper, are tentatively planned to assess the results of analyses results for the mode shape and force/dent characteristic. Depending on funding, component tests of shell strengthening and the sacrificial structure(s) may also be conducted.

\section{ACKNOWLEDGMENTS}

FRA Office of Research and Development sponsored the work described in this paper. Ms. Claire Orth is the Chief of the Equipment and Operating Practices Division. Mr. Francisco Gonzalez is the FRA program manager for research on railroad tank cars.

Mr. Grady Cothen, Deputy Associate Administrator for Safety Standards and Program Development, FRA, is leading the effort to develop tank car safety standards. Mr. Eloy Martinez, FRA program manager, is developing the technical information needed to support the FRA and PHMSA rulemaking effort. The authors thank Ms. Jo Strang, Associate Administrator for Safety Enforcement, FRA, for her efforts to coordinate the standards development and the tank car safety research.

The authors also thank Ms. Michelle Priante and Mr. Philip Mallon, Mechanical Engineers, Volpe Center, for their efforts in developing concepts for improving tank car safety. Dr. David Jeong, Senior Engineer, Volpe Center, is leading the effort to evaluate the performance of baseline equipment. Finally, the authors would like to thank Professor A. Benjamin

This material is declared a work of the U.S. Government and is not subject to copyright protection in the United States. Approved for public release; distribution is unlimited. 
Perlman, Senior Engineer, Volpe Center, for his assistance through all aspects of this project.

\section{REFERENCES}

[1] Federal Railroad Administration, "Development of New Federal Design Standards for Hazardous Materials Tank Cars to Benefit from Public-Private Partnership," U.S. Department of Transportation, FRA02-07, Tuesday, January 16, 2007.

[2] Tang, Y.H., Yu, H., Gordon, J.E., Priante, M., Jeong, D.Y., Tyrell, D.C., and Perlman, A.B., "Analysis of Full-Scale Tank Car Shell Impact Tests,” Proceedings of the 2007 ASME Rail Transportation Division Fall Technical Conference, September 11-12, 2007, Chicago, IL, RTDF2007-46010.

[3] Yu, H., Jeong, D.Y., Gordon, J.E., and Tang, Y.H., "Analysis of Impact Energy to Fracture Unnotched Charpy Specimens Made from Railroad Tank Car Steel," Proceedings of 2007 ASME Rail Transportation Division Fall Technical Conference, September 11-12, 2007, Chicago, IL, RTDF2007-460xx.

[4] Jeong, D.Y., Lyons, M.L., Orringer, O., and Perlman, A.B., "Equations of Motion for Train Derailment Dynamics," Proceedings of the 2007 ASME Rail Transportation Division Fall Technical Conference, September 11-12, 2007, Chicago, IL, RTDF2007-46009.

[5] Tyrell, D.C., Jeong, D.Y., Jacobsen, K., and Martinez, E.E., “Improved Tank Car Safety Research," Proceedings of the 2007 ASME Rail Transportation Division Fall Technical Conference, September 11-12, 2007, Chicago, IL, RTDF2007-46013.

[6] Paetsch, C.R., Perlman, A.B., and Jeong, D.Y., "Dynamic Simulation of Train Derailments," Proceedings of 2006 ASME International Mechanical Engineering Congress and Exposition, November 5-10, 2006, IMECE200614607.

[7] Jeong, D.Y., Tang, Y.H., and Perlman, A.B., "Engineering Analyses of Railroad Tank Car Head Puncture," Proceedings of 2006 ASME International Mechanical Engineering Congress and Exposition, November 5-10, 2006, IMECE2006-13212.

[8] Coltman, M., and Hazel, M., "Chlorine Tank Car Puncture Resistance Evaluation,” Volpe National Transportation Systems Center, Cambridge, MA, Report No. DOT/FRA/ORD-92/11, June 1992.

[9] Tyrell, D., Jacobsen, K., and Martinez, E., “A Train-toTrain Impact Test of Crash Energy Management Passenger Rail Equipment: Structural Results,” American Society of Mechanical Engineers, Paper No. IMECE2006-13597, November 2006.

[10] Martinez, E., Tyrell, D., Rancatore, R., Stringfellow, R., and Amar, G., "A Crush Zone Design for an Existing Passenger Rail Cab Car,” American Society of Mechanical Engineers, Paper No. IMECE2005-82769, November 2005.
[11] Martinez, E., Tyrell, D., and Perlman, A.B., “Development of Crash Energy Management Designs for Existing Passenger Rail Vehicles,” American Society of Mechanical Engineers, Paper No. IMECE2004-61601, November 2004.

[12]Mayville, R., Stringfellow, R., Johnson, K., and Tyrell, D., "Rail Vehicle Car Cab Collision and Corner Post Designs According to APTA S-034 Requirements," American Society of Mechanical Engineers, Paper No. IMECE200344114, November 2003.

[13] Parent, D., Tyrell, D., Rancatore, R., and Perlman, A.B., "Design of a Workstation Table with Improved Crashworthiness Performance," American Society of Mechanical Engineers, Paper No. IMECE2005-82779, November 2005.

[14]Severson, K., Tyrell, D., and Rancatore, R., "Crashworthiness Requirements for Commuter Rail Passenger Seats," American Society of Mechanical Engineers, Paper No. IMECE2005-82643, November 2005.

[15]Tyrell, D., Severson, K., Marquis, B., Martinez, E., Mayville, R., Rancatore, R., Stringfellow, R., Hammond, R., and Perlman, A.B., "Locomotive Crashworthiness Design Modifications Study," Proceedings of the 1999 IEEE/ASME Joint Railroad Conference, Catalog Number 99СH36340, 1999.

[16]Zolock, J., Tyrell, D., “Locomotive Cab Occupant Protection,” American Society of Mechanical Engineers, Paper No. IMECE2003-44121, November 2003.

[17] Association of American Railroads, Technical Services Division, Mechanical Section-Manual of Standards and Recommended Practices.

This material is declared a work of the U.S. Government and is not subject to copyright protection in the United States. Approved for public release; distribution is unlimited. 